[Agr. Biol. Chem., Vol. 28, No. 11. p. 809 810, 1964]

\title{
Microbial Phosphorylation of Pyridoxine
}

\section{- A New Phosphotransferring Reaction -}

Sir :

It has been demonstrated in mammalian tissues and microorganisms that the enzymatic phosphorylation of vitamin $B_{6}$ was catalyzed with pyridoxal phosphokinase in the presence of ATP. ${ }^{1}$

In the course of our investigations on the microbial phosphorylation of vitamin $B_{6}$, it was found that a new phosphotransferring system which phosphorylated pyridoxine with $p$-nitrophenylphosphate was widely distributed in various kinds of microorganisms, especially in fungi.

Table I. Phosphorylation of Pyridoxine

\begin{tabular}{lccccc} 
& \multicolumn{4}{c}{$\begin{array}{c}\text { Vitamin } \mathrm{B}_{6} \text {-P formed } \\
\end{array}$} & \multicolumn{4}{c}{ PIN-P* } & PAL-P** \\
\cline { 3 - 6 } \multicolumn{1}{c}{ Strains tested } & $p$-NPP*** & + & - & + & - \\
\hline Aspergillus tamarii & 22.8 & 0 & 2.4 & 1.6 \\
Aspergillus candidus & 29.2 & 1.2 & 4.4 & 1.4 \\
Aspergillus oryzae var. globosus & 28.4 & 0 & 3.6 & 1.2 \\
Aspergillus flarus & 37.8 & 0.9 & 5.4 & 1.3 \\
Penicillium oxalicum & 4.1 & 0 & 0.2 & 0 \\
Neurospora crassa & 2.7 & 0.3 & 1.7 & 0.8 \\
Endomyces fibuliger & 1.1 & 0.3 & 1.3 & 0.8 \\
Pichia polymorpha & 2.1 & 0 & 0.8 & 0.8 \\
Saccharomyces cerevisiae & 0.8 & 0.4 & 0 & 0
\end{tabular}

The reaction mixture containing, per $4 \mathrm{ml}$ of $10 \mu$ moles of pyridoxine hydrochloride, $50 \mu$ moles of disodium $p$ nitrophenylphosphate, $200 \mu$ moles of potasium phosphate buffer of $\mathrm{pH} 7.0,20 \mu$ moles of magnesium sulfate and $20 \mathrm{mg}$ of resting cells as dry matter was shaked for 14 hours at $29^{\circ} \mathrm{C}$.

* PIN-P: Pyridoxinc phosphate

** PAL-P: Pyridoxal phosphate

*** $p$-NPP : $p$-Nitrophenylphosphate

1) D. B. McCormick, M. E. Gregory and E. E. Snell, J. Biol. Chem, 236, 2076 (1961).
Table I shows the formation of vitamin $B_{6}$ phosphates from pyridoxine and $p$-nitrophenylphosphate by the cells of several microorganisms. This system was remarkably present in such genera as Aspergillus, Penicillium, Neurospora, Endomyces, Pichia, and Saccharomyces. In the case of Saccharomyces, the activity increased when the dried cells were used. Vitamin $B_{6}$ phosphate formed by these microorganisms was mainly pyridoxine phosphate. In some microorganisms, pyridoxine phosphate formed was partially oxidized to pyridoxal phosphate by pyridoxine phosphate oxidase.

Table II. The Specificity of Phosphate Donor

$$
\underset{(r / 4 \mathrm{ml})}{\text { Vitamin } \mathrm{B}_{6}-\mathrm{P} \text { formed }}
$$

\begin{tabular}{lcc}
\multicolumn{1}{c}{ Donor substrate } & Pyridoxine-P & Pyridoxal-P \\
\hline p-Nitrophenylphosphate & 3.6 & 1.9 \\
ATP & 0 & 0.4 \\
Glucose-1-P & 0.1 & 0.2 \\
$\alpha$-Glycerophosphate & 0.1 & 0.2 \\
Ribotide* & 0 & 0.3 \\
FMN & 0 & 0 \\
None & 0 & 0.2
\end{tabular}

The reaction mixture containing, per $2 \mathrm{ml}$ of $2 \mu$ moles of pyridoxine hydrochloride, $4 \mu$ moles of phosphate donor, $100 \mu$ moles of potassium phosphate buffer of $\mathrm{pH} 7.0$, $10, \mu$ moles of magnesium sulfate and $10 \mathrm{mg}$ of dried resting cells of Saccharomyces cerevisiae was incubated for 4. hours at $37^{\circ} \mathrm{C}$.

* Ribotide: Inosinic acid 10.8, Guanylic acid 33.1, Cytidylic acid 1.8 , Cridylic acid $1.4 \%$.

When dried cells of Saccharomyces cerevisiae were incubated with pyridoxine and various phosphate donors, $p$-nitropenylphosphate was more effective for the formation of vitamin $B_{6}$ phosphates than the other phosphate donors. 
(Table II)

These results suggest the occurrence of an enzyme which catalyzes the phosphorylation of pyridoxine with $p$-nitrophenylphosphate as an unphysiological phosphate donor.
Koichi Ogata

Yoshiki TANI

Shinpei Yamamoto

Tatsurokuro Tochrkura

Depariment of Agricultural Chemistry,

Kyoto Universiiy, Kyoto.

Received September 9, 1964 